\title{
Migraine days and body mass index (BMI) in a series of Japanese migraineurs
}

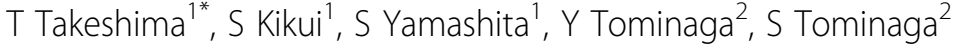 \\ From The European Headache and Migraine Trust International Congress \\ London, UK. 20-23 September 2012
}

Chronification of migraine headache is one of the most important issues. We analyzed possible association of migraine chronification and obesity in a Japanese series.

\section{Subjects and methods}

We have examined 2662 headache sufferers from February 2010 to March 2012 in our Headache Center. We interviewed all patients with structured questionears. Height and body weight were recorded. Types of headache were determined in accordance with ICHD-II criteria. 1356 subjects had migraine (M:F=349:1007; 152 with aura, 1204 without aura). Mean age of migraineurs was $37.8 \pm 15.0$ (SD) years old. According to BMI, subjects were categorized to five ranks, i.e., underweight (BMI< 18.5), normal (18.5-24.9), overweight (25-29.9), obese (30-34.9), and morbid obese $(>35)$. Average headache days and migraine days of recent three months were recorded. The data were analyzed with chi-square test and one-way ANOVA.

\section{Results}

94 out of 231 underweight migraineurs (40.1\%), 383 of 945 normal-weight ones (40.6\%), 61 of 139 overweight ones (43.9\%), 15 of 31 obese ones (48.4\%), and 9 of 10 morbid obese ones (90.0\%) had more than 15 headache days and 8 migraine days ( $<<0.05$, Pearson's chi-square test). Mean headache days were $13.9 \pm 0.7(\mathrm{SE}), 13.7 \pm 0.35,14.8 \pm$ $0.9,15.2 \pm 2.0$ and $20.5 \pm 2.5$ days/month in underweight, normal, overweight, obese and morbid obese migraineurs, respectively (N.S., ANOVA). Mean migraine days were $6.4 \pm 0.4,6.5 \pm 0.2,8.2 \pm 0.5,9.5 \pm 1.3$ and $12.5 \pm 1.3$, respectively ( $\mathrm{p}<0.0001$, ANOVA). BMI was significant risk factor after age adjustment $(\mathrm{p}<0.001$, partial correlation analysis).

${ }^{1}$ Neurology, Headache Center, Tominaga Hospital, Japan

Full list of author information is available at the end of the article

\section{Conclusion}

Overweight or obese migraineurs tended to have more migraine days than normal or underweight migraineurs in a Japanese series. Although the number of obese migraineurs is not large, obesity is a possible correctable risk factor for migraine chronification in Japanese population.

\section{Author details}

${ }^{1}$ Neurology, Headache Center, Tominaga Hospital, Japan. ${ }^{2}$ Neurosurgery,

Tominaga Hospital, Japan.

Published: 21 February 2013

doi:10.1186/1129-2377-14-S1-P127

Cite this article as: Takeshima et al:: Migraine days and body mass index (BMI) in a series of Japanese migraineurs. The Journal of Headache and Pain 2013 14(Suppl 1):P127.

\section{SpringerOpen ${ }^{\circ}$}

(C) 2013 Takeshima et al; licensee Springer. This is an Open Access article distributed under the terms of the Creative Commons Attribution License (http://creativecommons.org/licenses/by/2.0), which permits unrestricted use, distribution, and reproduction in any medium, provided the original work is properly cited.
Submit your manuscript to a SpringerOpen ${ }^{\circ}$ journal and benefit from:

- Convenient online submission

- Rigorous peer review

- Immediate publication on acceptance

- Open access: articles freely available online

- High visibility within the field

- Retaining the copyright to your article

Submit your next manuscript at $>$ springeropen.com 